Peranan dan Status Perempuan dalam Sistem Sosial

\title{
PERANAN DAN STATUS PEREMPUAN DALAM SISTEM SOSIAL
}

\author{
Puji Lestari ${ }^{1}$
}

\begin{abstract}
Abstrak
Kajian ini bertujuan untuk mengungkapkan tentang peran dan status perempuan dalam sistem social, yang terkait dengan realitas dalam kehidupan social khususnya pada aspek kehidupan rumah tangga, pembangunan, keluarga inti (extended family) dan keluarga luas (nuclear family) .

Peran dan satus perempuan dalam hal ini dapat terlhat melalui keterlibatan perempuan itu sendiri dalam ikatan kesatuan pada kelompokkelompok social yang diikutinya dalam kehidupan masyarakat, antara lain dalam kehidupan rumah tangga, keluarga, pembangunan dan sebagainya. Selanjutnya, dalam kelompok-kelompok social tersebut pada dasarnya memperlihatkan tentang bagaimana peran dan status perempuan itu, bagaimana ketergantungannya dengan individu-individu lain beserta unsurunsur social yang tergabung didalam kelompok tersebut, yang terintegrasi, bersifat lebih kekal dan stabil. Kondisi masyarakat seperti inilah yang pada dasarnya dapat dikatakan sebagai sistem social.

Peranan dan status itu sebenarnya merupakan unsur atau komponen yang tergabung dalm sistem social disamping unsur-unsur yang lainnya, begitu pula peranan dan status perempuan itu sendiri dalam suatu kelompok social pada kehidupan ini, karena dengan status dan peranan perempuan tersebut dapat menentukan sifat dan tingkatan kewajiban serta tanggung jawab didalam kelompok dimana si perempuan itu terlibat. Selain itu, juga dapat menentukan hubungan antara atasan dan bawahan secara terstruktur terhadap anggota lainnya yang tergabung didalm kelompok social tersebut. Status yang dimiliki oleh perempuan dalam hal ini merupakan serangkaian tanggung jawab, kewajiban, serta hak-haknya yang telah ditentukan dalam suatu kelompok atau masyarakatnya. Sedangkan pola tingkah laku yang diharapkan dari perempuan itu sendiri sebagai pemangku status dinamakan peranan. Peranan-peranan itu didalam kelompok social atau masyarakat saling berpadu sedemikian rupa dengan p;eranan anggota lainnya sehingga saling tunjangmenunjang secara timbale balik didalam sesjatu hal yang menyangkut tugas, hak dan kewajiban. Oleh karena itu, dapat dikatakan bahwa penampilan peranan (status-role performance) dari perempuan sebenarnya adalah sebagai proses penunjukkan atau penampilan dari satus dan peranan dari kelompok sosialnya sebagai unsur status social dalam sistem social.
\end{abstract}

Kata kunci: perempuan, sistem social, peran, status.

\footnotetext{
${ }^{1}$ Dosen Pendidikan Sosiologi, FIS, UNY. Mengampu mata kuliah sistem sosial, dasar sosiologi, sosiologi komunikasi, sosiologi pedesaan dan perkotaan
}

DIMENSIA, Volume 5, No. 1, Maret 2011 | 45 


\section{A. Pendahuluan}

Posisi permpuan dalam system social merupakan salah satu topik yang menarik untuk dikaji, karena selain meneropong perempuan dalam realitas kehidupan sosial juga melihat perempuan itu sendiri melalui fungsinya. Fungsi perempuan berbeda dengan laki-laki baik secara fisik maupun psikisnya. Perempuan bisa melahirkan anak sehingga mempunyai konsekuensi untuk bisa merawat, menyusui, mengasuh, memberikan kasih sayang dengan perasaan keibuan. Ini semua merupakan fungsi perempuan secara nyata dalam kehidupan masyarakat. Sementara itu fungsi laki-laki sebagai pencari nafkah karena mempunyai kondisi fisik yang kuat, sehingga bisa digunakan untuk bekerja lebih berat jika dibanding dengan perempuan.

Pembagian fungsi tersebut pada akhirnya akan menumbuhkan pembagian kerja secara generalisasi, meskipun antara keduanya itu (fungsi dan pembagian kerja) sebenarnya mempunyai perbedaan yang jelas. Hal ini dapat kita ketahui, bahwa fungsi itu merupakan potensi yang dimililiki manusia-manusia yang tidak akan berubah dan sama untuk setiap manusia, sedangkan pembagian kerja lebih mengarah pada keterampilan individu dan tergantung pada bargaining pelakunya. Pembagian kerja secara generalisasi seperti itu, sebenarnya membuat posisi perempuan kadang kala tidak menguntungkan, karena perempuan berkewajiban untuk bekerja di dalam rumah tangga, kemudian laki-laki berkewajiban bekerja di luar rumah. Kondisi semacam ini telah disadari oleh para perempuan karena mereka benar- benar mengetahui bahwa masyarakat itu mengharapkan perubahan tersebut dapat terlihat melalui peran perempuan menjadi istri dan ibu, dan hingga beberapa waktu yang lalu bahkan sampai sekarangpun nilai-nilai yang mengharuskan perempuan mengurus rumah tangga, masih dipegang teguh oleh berbagai kalangan masyarakat.

Pembagian

secara generalisasi telah lama mengakar pada masyarakat, meskipun pada saat ini telah mengalami perubahan sedikit demi sedikit pada sebagian kecil masyarakat, namun masih kelihatan dengan jelas. Perubahan tersebut dapat terlihat melalui peran laki-laki dan perempuan dalam suatu rumah tangga yang keduanya antara suami dan istri sama-sama bekerja di luar rumah mencari nafkah untuk kehidupan keluarganya. Laki- laki sebagai suami, karena istrinya merangkap bekerja di dalam rumah tangga dan di luar rumah tangga untuk membantu beban suami dalam mencari nafkah, maka suami sebisabisanya berupaya membantu tugas istri dalam mengerjakan pekerjaan rumah tangga tersebut. Hal ini dilakukan karena ada kesadaran dari pihak suami, bahwa istri bekerja di luar rumah kerena membantu beban suami, maka suami juga rela membantu pekerjaan istri dari pada pekerjaan di dalam rumah tangganya kacau balau dan kondisi serta situasi 
Peranan dan Status Perempuan dalam Sistem Sosial

rumah tangganya tidak nyaman lagi pula tidak menyenangkan bagi semua anggota keluarganya. Namun hal ini nampak ada pada sebagian kecil rumah tangga saja, terutama yang pasangan suami istri memiliki pendidikan dan pengetahuan cukup tinggi (Mansour faqih, 1997:103).

Kondisi seperti tersebut di atas bisa terjadi karena dengan pendidikan dan pengetahuan yang cukup tinggi, dimungkinkan lebih bisa mencerna dan dan menerima nilai-nilai baru pada aspek-aspek kehidupan yang dirasa perlu untuk memperbaiki situasi dan kondisi tentang kehidupan sebelumnya. Namun keterlibatan suami di dalam mengerjakan tugas rumah tangga tersebut masih terlihat canggung, karena hal itu oleh masyarakat masih dianggap sebagai sebagai pelanggaran terhadap norma-norma yang berlaku dalam masyarakat setempat. Kenyataan seperti ini dapat kita cermati dalam kehidupan sehari- hari, antara lain suami meskipun sudah tulus dan ikhlas ikut terlibat mengerjakan tugas rumah tangga: mencuci piring, mencuci pakaian, menyapu lantai, dan sebagainya, akan tetapi jika dilihat orang lain seperti teman tetangga, sanak saudara, dan sebagainya ia merasa malu. Ini berarti bahwa di satu sisi sudah ingin merubah adanya pengkotakkotakan pekerjaan secara seksual, namun di sisi lain masih harus menyesuaikan dan bahkan berpegeng teguh pada nilai dan norma yang ada dalam masyarakat.
Begitu pula pada istri, jika ia bekerja di luar rumah sampai larut malam, ikut mengerjakan pekerjaan dalam memperbaiki sepeda motor yang rusak, mencangkul di sawah, dan sebagainya dirasa tidak lazim.

Uraian di atas menunjukkan adanya kenyataan bahwa dalam kehidupan masyarakat terdapat budaya yang menampilkan mana fungsi yang pantas bagi laki-laki dan perempuan. Jika kita cermati image yang dibangun masyarakat tentang kerangka laki-laki lebih menguntungkan daripada perempuan. Laiki-laki diberi image sebagai sosok yang kuat, tidak cengeng, kokoh, handal, cerdas, dan sebagainya. Di samping itu laki-laki juga dituntut untuk mampu menghadapi segala permasalan dan tantangan kehidupan sendiri. Sementara itu perempuan diberi image sebagai sosok yang manis, lemah-lembut, cengeng, ketergantungan dengan orang lain, sehingga tidak menutup kemungkinan perempuan tersebut akan mengharap bantuan orang lain dalam mengatasi segala masalah yang muncul dan dihadapi dalam kehidupan ini.

Kebiasaan semacam itu bagi perempuan seolah-olah sudah menjadi tradisi yang pada akhirnya akan menciptakan sikap yang tidak mandiri bagi perempuan itu sendiri. Dengan demikian bisa dikatakan, bahwa sampai sekarangpun kehidupan masyarakat ini akan memberikan kesempatan bagi perempuan untuk tidak mengembangkan kemandiriannya. 
Kondisi masyarakat seperti itu sebenarnya yang bisa memberikan sistem kepercayaan gender.

Sistem kepercayaan gender mencakup diskriftif mengenai kepercayaan tentang bagaimana sebenarnya laki-laki dan perempuan itu, dan pendapat tentang bagaimana seharusnya laki-laki dan perempuan itu (Deauk dan Kite, dalam Susilastuti, 1993: 30). Hal ini memberi gambaran dan pengertian yang jelas pada kita, tentang adanya beberapa stereotype gender dan kepercayaan tentang apa yang seharusnya dilakukan oleh laki-laki dan perempuan yang sampai sekarang masih tetap ada dalam kehidupan masyarakat, ini memang benar-benar ada dasar kenyataannya. Namun tidak dapat disangkal lagi jika muncul pertanyaan bahwa kepercayaan orang bukanlah merupakan gambaran akurat suatu realitas, karena mengandung bias persepsi dan kesalahan interpretasi (Susilastuti, 1993: 31). Tentunya hal ini bisa terjadi sebagai akibat dari adanya kenyataan, bahwa dalam kehidupan masyarakat berkembang adanya kepercayaan gender melalui individu-individu yang mempunyai persepsi dan interpretasi yang tidak sama antara satu orang dengan orang yang lain dipengaruhi oleh tingkat pendidikan, pengalaman, dan suatu pengetahuan, sehingga menghasilkan anggapan-anggapan mengenai citra perempuan dan lakilaki yang berbeda-beda, dan tidak sesuai dengan realitas dasarnya.

\section{B. Realitas perempuan dalam kehidupan rumah tangga}

Berbagai literature studi perempuan, pada umumnya terdapat dua pandangan yang berlawanan mengenai "rumah tangga". Pertama, adanya pandangan yang melihat rumah tangga sebagai sumber subordinasi perempuan. Pandangan ini beranggapan bahwa posisi rendah perempuan di pasar tenaga kerja (upah rendah atau pekerjaan yang dinilai lebih rendah dari pekerjaan laki-laki dan tidak membutuhkan keterampilan yang tinggi). Hal ini disebabkan karena posisi mereka di dalam rumah tangga dimana lakilaki lebih tinggi daripada perempuan. Struktur kerja yang seperti ini menguntungkan bagi kaum laki-laki, karena dengan cara demikian mereka dapat bebas menjual tenaga kerja mereka di pasar tenaga kerja tanpa harus mengurus kebutuhan hidup seharihari (Ratna Saptari dkk., 1997: 23).

$$
\text { Begitu pula dalam }
$$

pendistribusian kembali hasil kerjapun, kaum perempuan terasa dirugikan. Telah banyak studi yang menunjukkan tentang bagaimana seorang ayah mendapat prioritas paling tiggi dalam pembagian konsumsi. Sedangkan Si Ibu dan anak-anak tidak begitu diutamakan. Kerangka pandangan yang demikian ini menunjukkan adanya kenyataan bahwa rumah tangga dilihat sebagai wadah dimana terdapat perbedaan kepentingan dan terdapat keteganganketegangan yang pada umumnya diselesaikan dengan menggunakan garis otoritas ayah.

Kedua, pandangan yang melihat rumah tangga sebagai 
Peranan dan Status Perempuan dalam Sistem Sosial

sumber dukungan solidaritas perempuan. Pandangan ini terutama melihat dampak negative dari proses kapitalisme atau gejala rasialisme terhadap individu. Dalam kerangka pandangan ini rumah tangga dilihat sebagai tempat perlindungan, dukungan, dan sumber kekuatan untuk melakukan perlawanan atau sekedar untuk bertahan. Hubungan kekeluargaan di dalam rumah tangga yang seperti ini menyediakan dukungan material disaat menghadapi pengangguran, sakit, dan malapetaka lainnya (Humtries dalam Ratna Saptari, 1997: 24).

Walaupun kedua pandangan ini saling berbeda dan bahkan saling bertolak belakang, tapi dalam kenyataannya antara keduanya tidak saling menolak terhadap pandangan-pandangan yang lainnya. Hal ini seperti apa yang dinyatakan oleh Gita Sen dalam kutipan Ratna Sapari (1997): bahwa disatu pihak tidak dapat disangkal lagi bahwa bagi seseorang dari rumah tabngga kelas bawah, misalnya saja dari sudut ekonomi dibutuhkan sumbangan dan kerjasama rumah tangga lainnya untuk bisa meneruskan kelangsungan hidupnya. Di lain pihak, apabila hubungan antar anggota diteliti, sering kali terdapat ketimpangan antara anggota lakilaki dan perempuan sebagaimana dipaparkan di atas, pada pandangan pertama yang mempengaruhi sepak terjang perempuan di luar rumah.
Pandangan semacam ini ada dasarnya akan memunculkan suatu masalah bahwa dalam konteks yang bagaimana rumah tangga itu merupakan dasar aliansi kuat untuk menghadapi kesulitan-kesulitan ekonomi dan sosial di dunia luar, dan dalam konteks bagaimana rumah tangga menjadi penyebab atau penghambat kemandirian perempuan.

Masalah tersebut tidak bisa diatasi dengan mudah, kerena struktur dan fungsi rumah tangga itu sendiri beserta bentuk dan sifatsifat hubungannya dengan dunia luar sangat kompleks, sehingga memunculkan keanekaragaman kondisi rumah tangga itu sendiri yang kemudian bisa memperlihatkan konsep tentang rumah tangga kadangkala terjebak dalam mitos-mitos yang sering tidak sesuai dengan kenyataan dalam studi empiris. Adapun mitosmitos yang paling utama ialah bahwa rumah tangga yang merupakan satu kesatuan di mana anggotanya mempunyai kepentingan dan suara yang selalu sama. Mitos ini muncul karena terjadi pencampuradukan antara individu dengan rumah tangga. Padahal keduanya itu berbeda dalam konsep, dan begitu pula dalam tingkatan analisispun jelas berbeda. Hal ini bisa kita cermati melalui berbagai studi yang menunjukkan bahwa pembagian kerja dan pengambilan keputusan dalam rumah tangga bisa menjadi sumber konflik di antara anggota rumah tangga itu sendiri. Misalnya 
saja dalam rumah tangga ada seorang ibu yang berjualan makanan, maka ia akan membutuhkan tenaga anak perempuannya untuk belanja di pasar, kemudian juga membantu memasak dan sebagainya. Hal itu berarti bahwa kepentingan yang tercermin dalam kondisi seperti itu bisa dikatakan sebagai kepentingan yang ditujukan untuk kelangsungan hidup seluruh rumah tangga yang betul-betul berlawanan dengan kepentingan seorang anak perempuan yang ingin mempunyai upah sendiri dan bekerja dengan orang-orang yang sebaya dengan dirinya di luar rumah tangganya.

Segala kemungkinan ini menyebabkan orang semakin menyadari, bahwa pemahaman tentang arti dan fungsi rumah tangga bagi kaum perempuan hanya bisa diketahui apabila kita bisa mengungkap konsep rumah tangga dari segala pandangan keliru yang melingkupinya (Ratna Saptari, 1997: 36). Mengenai bagaimana rumah tangga sebagai unit sosial yang sekaligus merupakan suatu system sosial dalam lingkup yang kecil dan khusus, antara lain bisa mencerminkan posisi perempuan sebagai berikut. Setiap individu dalam kehidupan masyarakat harus mengalami proses sosialisasi terlebih dahulu, yaitu suatu proses di mana seseorang mempelajari nilai serta norma yang terdapat dalam kehidupan masyarakat. Masyarakat yang pertama kali memberikan sosialisasi pada setiap individu termasuk perempuan adalah lingkungan rumah tangga ataupun keluarga. Biasanya dalam rumah tangga itu untuk pertama kali peran atas gender dipelajari. Namun, dalam usaha merekontruksi (membongkar, memilah kembali) konsep rumah tangga. Selanjutnya para peneliti kemudian menyadari bahwa di satu pihak memang sosialisasi nilai dan norma itu terjadi dalam rumah tangga yang berasal dari lapisan bawah akan disosialisasikan ke nilai-nilai yang berbeda dengan anggota rumah tangga yang berasal dari lapisan atas. Di lain pihak karena pengalaman anggota rumah tangga tidaklah sama, dan interaksi dengan dunia luar berbeda-beda pula, maka seringkali ada pertentangan nilai atau ideology di antara anggota dalam satu rumah tangga sekalipun. Begitu pula derajat keterbukaan antar setiap rumah tangga terhadap nilai-nilai baru atau yang berbeda seringkali tidak sama pula. Hal ini dapat kita cermati bahwa dalam kehidupan masyarakat ini pada realitasnya perempuan kadangkala dikatakan lebih konservativ dalam menerima nilai-nilai baru. Walaupun pernyataan ini merupakan generalisasi yang bersifat sementara dan belum tentu berlaku secara umum, akan tetapi jika hal ini terjadi mungkin disebabkan karena adanya persinggungan ataupun interaksi perempuan dengan dunia luar lebih kecil daripada kaum lakilaki. Begitupula tanggung jawab reproduksi keluarga serta pelestarian posisi keluarga tersebut jatuh di pundak perempuan.

Pada umumnya perempuan sebagai ibu rumah tangga di seluruh dunia melakukan berbagai 
Peranan dan Status Perempuan dalam Sistem Sosial

macam tugas yang memiliki satu kesamaan mata rantai rumah dengan penghuninya. Mereka merawat anak, memenuhi suplai pangan keluarga baik dari ladang keluarga atau pasar swalayan setempat. Mereka juga ikut memberi penghasilan bagi keluarganya melalui pekerjaan paruh waktu yang tidak membahayakan pekerjaan utamanya yakni mengurus rumah dan keluarga. Namun yang menjadi masalah penting dalam kaitannya dengan peran perempuan tersebut adalah adanya pertautan tentang apa yang dilakukan oleh perempuan tersebut dalam kaitannya dengan keadaan dan di mana mereka melakukannya. Jadi seolah-olah apa yang dilakukan perempuan itu sendiri tidak mendapat perhatian secara khusus.

Sebagaimana kita ketahui, pekerjaan rumah tangga itu sebenarnya adalah satu aspek pembagian kerja berdasarkan gender, di mana laki-laki cenderung melakukan pekerjaan yang dibayar dan perempuan mengerjakan pekerjaan yang tidak dibayar (Mosse, 1992: 45). Lebih lanjut Mosse menyatakan bahwa dalam proses industrialisasi (hingga pada akhir-akhir ini ketika hubungan gender di dalam perburuhan mulai berubah), cenderung tertuju kepada buruh laki-laki. Pada berbagai Negara, perempuan mendapati dirinya tersisih dari pekerjaan sector formal melalui serikat buruh yang didominasi oleh laki-laki, sedangkan perempuan lain. Mereka cenderung terus melakukan apa yang selalu dilakukannya. Perbedaannya adalah bahwa tentang keadaannya di mana mereka melakukan pekerjaannya berubah dari perekonomian substitensi kepada perekonomian uang. Sebagi contoh adalah pada perempuan di komunitas Turkana tatkala ada penawaran proyek pembangunan tentang pertanian menetap yaitu menanam tanaman yang dijualbelikan untuk kepentingan eksport. Jika peluang kerja yang muncul sebagian besar ditawarkan kepada laki-laki maka perempuan Turkana akan mendapati dirinya berada di tepi perekonomian uang tunai dan memiliki akses terhadap uang tunai tersebut, dalam arti perempuan hanya bisa menerima uang dan mendistribusikannya pada kebutuhan rumah tangganya saja. Mereka kemudian hanya mengurusi anak, memelihara ternak, dan mempertahankan sisa-sisa gaya hidupnya terdahulu.

Pada saat seperti itu ketergantungan perempuan pada laki-laki mungkin bisa berkembang, sementara dalam rumah tangga yang dulunya perempuan dan lakilaki melakukan tugas yang dipandang sama-sama penting, setelah ada pengenalan dengan uang dan akses terhadap hal-hal yang dapat dibeli, kemudian status pekerjaan masing-masing mitra menjadi berubah. Laki-laki akan mendapati akses terhadap pranata modern yaitu bank dan fasilitas yang luas, sedangkan perempuan 
akan tetap tertinggal jauh di belakang.

Paparan di atas memberikan gambaran pada kita bahwa di dalam perekonomian modern uang dan barang maupun jasa yang dapat dibeli, menjadi ukuran status dan jabatan. Oleh karena itu yang menjadi masalah pada kaum perempuan khususnya ibu rumah tangga dalam hal ini adalah bukan sifat actual dari pekerjaan yang dilakukannya, meskipun mungkin membosankan dan bersifat ulangan, lagi pula menuntut ketelatenan dan perhatian yang khusus serta memerlukan waktu yang cukup panjang, tetapi dalam kenyataannya pekerjaan actual yangn dikerjakan perempuan tersebut tidak dibayar dan tidak ada status yang dilekatkan padanya.

Kondisi perempuan dalam kehidupan rumah tangga di Indonesia pada saat ini bisa dikatakan sebagai manusia yang hidup dalam dilematis. Di satu sisi perempuan dituntut untuk berperan dalam semua sektor, tetapi di sisi lain muncul pula tuntutan lain agar wanita tidak melupakan kodrat mereka sebagai wanita (Sutrisno, 1993: 108). Situasi ini terutama dihadapi oleh wanita karier pada golongan kelas menengah ke atas. Wanita karier tersebut di satu sisi merasa terpanggil untuk mendarmabaktikan bakat dan keahliannya bagi perkembangan bangsa dan Negara, di pihak lain mereka merasa dihantui oleh opini di kalangan masyarakat yang beranggapan bahwa perempuan sebagai ibu rumah tangga yang berkarier, merupakan wanita yang tidak akan berhasil dalam membina rumah tangganya, karena perhatian mereka tidak akan terfokus pada satu tugas pokok, yaitu sebagai pengelola rumah tangga, akan tetapi perhatiannya terbagi kepada dua tugas yang kesemuanya menuntut untuk diutamakan dalam pelaksanaannya. Bahkan sampai sekarang masih ada pendapat yang menyatakan, bahwa perempuan sebagai ibu rumah tangga harus selalu ada di tengah-tengah keluarganya, oleh karena itu mereka bisa mencari pekerjaan di luar rumah apabila keluarga benar-benar membutuhkan dan memberikan izin.

Cerminan dilematis wanita seperti di atas,pada masyarakat Jawa yang sampai sekarang masih ada, misalnya saja adanya anggapan bahwa perempuan itu adalah sebagai "konco wingking" yang bertugas mengurusi rumah tangga. Selain itu ada ungkapan yang menyatakan, bahwa suami adalah "guru laki-laki" yang artinya suami bertanggung jawab terhadap kesejahteraan material juga berkewajiban seperti halnya guru bagi istrinya agar tidak berbuat sesuatu yang tidak sesuai dengan ajaran agama ataupun adat (Sutrisno, 1993: 110). Padahal sebenarnya dalam kehidupan rumah tangga, tidak hanya suami saja yang sebagai guru istri, tapi istri juga bisa sebagai guru suami jika berbuat sesuatu yang tidak sesuai dengan ajaran agama dan adat, karena dalam proses sosialisasi keluarga keduanya (suami dan istri) sama-sama mempunyai peran yang penting untuk saling mendidik agar 
Peranan dan Status Perempuan dalam Sistem Sosial

suami dan istri tersebut beserta anggota keluarga yang lain tidak terjerumus dalam dosa-dosa karena melanggar norma-norma agama.

Paparan di atas kiranya bisa memberikan gambaran, bahwa pada umumnya perempuan yang dihadapkan pada dilematis dalam kehidupannya, dan di dalam rumah tangga masih terasa diposisikan tidak sejajar dengan pria meskipun pada saat-saat sekarang sudah ada pergeseran dan sedikit mengalami perubahan. Namun sisa-sisa anggapan yang memposisikan wanita seperti itu masih banyak berkembang dalam kehidupan sehari-hari di kalangan keluarga ataupun rumah tangga di Indonesia, terkecuali ada beberapa suku bangsa yang memang memposisikan perempuan sejajar dengan pria, bahkan lebih tinggi daripada pria seperti di masyarakat Minangkabau. Kondisi seperti tersebut diatas pada akhirnya menciptakan suasana kehidupan yang tidak mampu mengembangkan diri dan berkarya secara otonomi bagi bangsa dan negara. Oleh karena itu kondisi tersebut perlu dihilangkan dengan strategi yang tepat dan mengacu pada sebab-sebab terjadinya kondisi tersebut.

\section{Peran Perempuuan dalam Pembangunan}

Perempuan pada masyarakat modern dewasa ini dintuntut untuk berpartisipasi secara aktif dalam pembangunan, yang merupakan salah satu azas pemerataan yang dituju dalam salah satu PELITA kita. Perempuan dalam hal ini mendapat kesempatan untuk mewujudkan potensi-potensinya secara optimal. Hal ini merupakan kebutuhan perempuan yang harus dipenuhinya, dan tidak sedikit pula bagi perempuan Indonesia yang telah berupaya memenuhi kebutuhan tersebut baik yang masih berstatus "lajang" maupun yang telah berumah tangga.

Kondisi seperti ini bisa kita cermati secara empirik, bahwa pada zaman dahulu kebutuhan perempuan pada umumnya terbatas pada kebutuhan fisiologis, kebutuhan akan rasa aman, dan perlindungan, kebutuhan akan cinta dan"belonging" (social needs), sedangkan pada masa sekarang dapat mengikuti pendidikan, bekerja di kantor ataupun menduduki jabatan kepemimpinan, dan bahkan kebutuhan akan prestasi serta perwujudan diri, aktualisasi diri bisa dirasakan dan dipenuhi oleh sebagian besar perempuan di Indonesia (Sri Indiyah dalam Fauzie Rizal dkk, 2002: 126).

Paparan di atas menunjukkan bahwa status perempuan di Indonesia telah mencapai perkembangan yang cukup tinggi. Dengan status tersebut, seorang perempuan dapat menentukan sifat dan tingkatan kewajiban serta tanggung jawab di dalam suatu kelompok masyarakat. Di samping itu juga menentukan hubungan antara atasan dan bawahan terhadap anggota lain 
dalam kelompok masyarakat di mana mereka terlibat di dalamnya. Status itu sendiri merupakan serangkaian tanggung jawab serta hak-hak yang sudah ditentukan dalam masyarakat. Sedangkan pola tingkah laku yang diharapkan dari orang-orang pemangku status dinamakan peranan. Selanjutnya peranan-peranan sosial saling berpadu sedemikian rupa sehingga saling tunjang- menunjuang secara timbal balik di dalam hal yang menyangkut tugas, hak, dan kewajiban. Oleh karena itu suatu penampilan peranan status (status role performance) adalah proses penunjukkan atau penampilan dari status dan peranan sebagai unsure struktur sosial di dalam kehidupan sosial.

\section{Peran Perempuan dalam Keluarga}

Sebagaiman kita ketahui, keluarga itu sendiri dapat dilihat dalam arti kata yang sempit yaitu sebagai keluarga inti (exstended family) yang merupakam kelompok sosial terkecil dari masyarakat, yang terbentuk berdasarkan pernikahan dan terdiri dari seorang ayah (suami), ibu (istri), dan anak-anak yang di dalamnya dilandasi oleh cinta dan kasih sayang di antara anggotanya. Keluarga inti sebagai kelompok primer yang terkait oleh hubungan intim mempunyai fungsifungsi utama sebagai berikut:

- Pemberian afeksi, dukungan, dan persahabatan

- Memproduksi dan membesarkan anak
- Meneruskan norma-norma kebudayaan, agama, dan moral pada yang muda

- Mengembangkan kepribadian

- Membagi dan melaksanakan tugas-tugas di dalam keluarga maupun di luarnya (Utami Munandar, 1995:39).

Semua fungsi tersebut melibatkan partisipasi perempuan untuk melaksanakan peranannya sebagai ibu rumah tangga meskipun laki-laki sebagai suami ikut andil di dalamnya. Mulai dari fungsi yang pertama sampai yang terakhir dilakukan oleh perempuan sebagai ibu rumah tangga terhadap anakanak mereka semenjak anak-itu lahir sampai masuk sekolah dan hingga dewasa. Hal ini dapat kita mengerti bahwa di kalangan perempuan sebagai ibu rumah tangga mempunyai anggapan bahwa tugas utama seorang ibu adalah merawat anaknya, antara lain merawat, menjaga kesehatannya, memperhatikan gizi makanan, mengusahakan agar pakaian anak selalu rapih dan bersih. Mengajarkan sopan santun serta tata pergaulan dan sebagainya.

Memang betul bahwa dalam kenyataannya setiap anak dilahirkan dengan cirri-ciri dan bakat yang berbeda-beda namun potensi atau bakat tersebut menentukan limit atau batas-batas dari perkembangan anak, meskipun sebenarnya limit ini tidak pernah ataupun jarang sekali tercapai. Namun tugas seorang pendidik dalam keluarga yaitu perempuan sebagi ibu rumah tangga 
Peranan dan Status Perempuan dalam Sistem Sosial

mengusahakan suatu lingkungan pendidikan yang optimal, dalam hal ini yang dimaksud dengan pendidikan ialah segala pengaruhpengaruh yang diterima oleh individu sejak lahirnya, bukan sejak ia masuk sekolah (Utami Munandar, 1995: 45).

Sebenarnya seorangn perempuan sebagi ibu rumah tangga merupakan guru yang pertama dan yang paling utama bagi seorang anak. Ini semua dikarenakan seorang ibulah yang paling banyak mempunyai kesempatan untuk membentuk kepribadian dan kemampuan anak, mengajarinya dengan memberikan perhatian yang khusus, sesuai dengan kondisi anak dalam waktu dan pada saat-saat di mana anak paling senang atau merasa tertarik untuk belajar.

Seorang perempuan sebagai ibu rumah tangga cukup mempunyai waktu dan kesempatan untuk mengamati dan mengenal anaknya sebagi individu, tidak hanya sebagai anggota kelompok. Selain itu, ibulah yang paling tau tentang minat anaknya, tau pula jika anak perlu dorongan atau pujian serta tau pula untuk tidak memberikan ancaman, ejekan, kemarahan, hukuman fisik, dan sebagainya dalam memotivasi dan menaikkan rasa harga diri serta percaya diri pada anak. Selanjutnya anak-anak yang mendapat kesempatan untuk mengembangkan potensinnya secara optimal akan tumbuh menjadi anak-anak yang bahagia, kreatif dan produktiv sehingga mereka akan lebih mampu menghadapi bermacam-macam masalah dan tantangan dalam kehidupan.

Selain itu perempuan sebagai orang tua dan ibu rumah tangga mempunyai jalinan hubungan yang kuat dengan anak dalam proses pembentukan dan perkembangan kepribadian anak, sebab orang tua terutama ibulah yang merupakan orang pertama dan dikenal oleh $\mathrm{Si}$ Anak. Melalui orang pertama inilah Si Anak mendapatkan kesan-kesan pertama tentang dunia luar. Bagi seorang bayi/anak kecil hubungan afektif dengan orang tuanya merupakan factor penentu agar ia dapat "survive".

Menurut hasil penyelidikan Rene Spitz dalam kutipan Utami dinyatakan, bahwa tanpa cinta kasih ini seorang bayi tidak bisa hidup terus, oleh karena itu memperoleh cinta kasih merupakan kebutuhan dasar seperti makan dan tidur. Pemenuhan terhadap kebutuhan ini tentu saja tidak bisa lepas dari orang tua terutama perempuan sebagai ibunya. Seorang ibu dalam hal ini membimbing terhadap tingkah laku anak mereka dengan berbagai cara misalnya saja menerima, menyetujui, membenarkan ataupun menolak, melarang dan sebagainya terhadap tingkah laku anak mereka. Pemberian nilai tingkah laku yang seperti ini maka terbentuklah dalam anak tentang norma-norma dan nilai-nilai social dengan berbagi jenis dan tingkatannya yang secara sosiologis mencakup cara, kebiasaan, tata kelakuan, dan adat 
istiadat. Dengan demikian terbentuklah hati nurani anak yang kemudian akan mengarahkan ke tingkah laku selanjutnya dalam kehidupan bermasyarakat.

Peran perempuan dalam keluarga selain berkontribusi penting dalam proses pembentukan kepribadian dan mental anak seperti tercermin pada paparan di atas, ia juga bertugas melaksanakan fungsinya yang berkaitan dengan status istri bagi suaminya. Hal ini bisa kita pahami karena keluarga itu terbentuk jika ada ikatan perkawinan antara seorang laki-laki dan perempuan. Jika ini terjadi maka dua mahluk dari seks yang berlainan, dengan cirri-ciri kepribadian yang berbeda, mengikat diri untuk selanjutnya mereka hidup bersama. Oleh karena itu antara kedua belah pihak harus ada masa "penyesuaian kepribadian". Adapun proses penyesuaian diri ini dilakukan secara terus-menerus.

Sebagaimana kita ketahui, antara laki-laki dan perempuan terdapat perbedaan-perbedaan dan hal ini memang merupakan warisan biologis (nature), tetapi ada pula yang lebih menekankan pengaruh dari kebudayaan di mana mereka itu hidup (nurture). Hal ini seperti apa yang dimukakan oleh Margaret Meat bahwa cirri-ciri yang dianggap khas untuk seorang perempuan dalam kehidupan lain justru ditemukan pada pria. Jadi apakah perbedaan-perbedaan itu merupakan akibat dari "nature" atau "nurture" belum bisa ditentukan dengan pasti, yang jelas antara keduanya itu harus ada penyesuaian diri. Penyesuaian diri itu sendiri tidak harus merubah dirinya untuk dicocokan terhadap yang lain, akan tetapi dengan adanya pengertian untuk perbedaan-perbedaan tersebut kemudian dilakukan hal-hal yang bisa menambahkan kepuasan dalam hubungan mereka.

Untuk mencapai hubungan yang harmonis, faktor tentang adanya saling pengertian merupakan kunci yang paling utama. Memahami tentang motifmotif tingkah lakunya, berusaha mengerti tentang kebiasaankebiasaannya, dan sebab-sebab mengapa ia berbuat demikian beserta latar belakang hidupnya dan sebagainya. Ini semua pada dasarnya juga akan menciptakan sikap dan perilaku yang toleran di antara mereka. Toleransi itu merupakan hal yang sangat penting dalam membina hubungan yang harmonis antara perempuan dan laki-laki sebagai istri dan suami dalam keluarga. Toleransi dalam hal ini meliputi: tentang toleransi terhadap kekurangan-kekurangan, kelemahan-kelemahan, ataupun kebiasaan-kebiasaan yang kurang baik dari pihak yang lainnya. Selain itu juga adanya rasa bahagia dan kepuasan, saling menghargai antar keduanya, penghargaan akan kepribadiannya, prestasi, minat individualitas dari mereka berdua. Dengan demikian jika seorang lakilaki dan perempuan telah mengikat diri dalam hubungan perkawinan berarti mereka telah bertanggung jawab atas hubungan tersebut, atas hidup partnernya dan segala akibat dari hubungan itu. Di samping itu 
mereka harus menginsyafi bahwa keduanya itu merupakan kesatuan baik ke dalam maupun ke luar. Masing-masing hendaknya selalu bersedia untuk membantu yang lainnya, sifat gotong royong, kesetiaan, dan sebagainya sangat diperlukan untuk menjalin hubungan laki-laki dan perempuan dalam suatu ikatan perkawinan. Masing-masing harus mempunyai keyakinan, bahwa partnernya tidak akan meninggalkannya, akan tetapi mau berkorban untuknya. Kesemuanya itu akan memberikan rasa keamanan pada diri mereka masing-masing.

Untuk proses pelaksanaan itu semua tentu saja tidak bisa lepas dari adanya unsur perasaan (sentimen) dari kedua belah pihak antara laki-laki sebagai suami dan perempuan sebagai istri, sehingga bisa menciptakan suasan yang kondusif, bahagia, aman, dan tenteram. Perasaan (sentimen) itu sendiri menurut Alfin dalam kutipan Abdulyani, 2002: 126 menunjuk pada bagaimana perasaan pada anggota sistem social (anggota kelompok), tentang hal-hal atau peristiwa serta temapt-tempat tertentu. Unsur-unsur perasaan ini sangat membantu dalam rangka menjelaskan pola-pola tingkah laku yang tidak dapat dijelaskan melalui cara lain. Suatu keberhasilan sistem sebenarnya juga tergantung bagaimana perasaan para anggotanya secara umum. Oleh karena itu jika dalam suatu sistem di antara anggota-anggotanya saling menaruh perasaan dendam, benci, dan iri hati antara satu dengan yang lainnya, maka bisa diketahui bahwa hubungan kerjasamanya tidak akan berhasil dengan baik (Abdulyani, 2002: 126).

Cerminan perempuan dalam sistem social, selain keterlibatannya pada berbagai posisi dalam kehidupan social termasuk dalam hal ini pada keluarga inti sebenarnya masih banyak pula pada kelompok social dalam kehidupan lainnya, antara lain pada keluarga yang lebih luas lagi. Hal ini dimungkinkan karena hidup seorang perempuan yang telah berkeluarga disamping perannya sebagai istri, sebagai ibu, dan sebagai pengurus rumah tangga juga dapat berperan sebagai anggota keluarga tingkat RT, anggota keluarga arisan dan sebagainya. Oleh karena itu, bagi setiap perempuan hendaknya menyadari dengan bermacammacam perannya dan tahu pula apa yang diharapkan dari padanya sebagai anggota keluarga inti maupun sebagai aggota kelarga yang lebih luas. Adanya penyesuaian diri, saling pengertian, toleransi, saling harga menghargai hak atas kehidupan pribadi, tanggumg jawab, gotong royong adalah penting dalam hubungan antar manusia. Dengan demikian dalam hubungan sebagai anggota keluarga inti maupun keluarga luas serta masyarakat indonesia hendaknya selalu diusahakan adanya perwujudan diri dari setiap individu sesuai dengan bakat, kemampuan, dan ciri-ciri khasnya 
disatu pihak dan disamping itu juga diperlukan penyesuaian diri terhadap lingkungannya dimana penyesuaian diri tidak diartikan secarapasif bamun aktif ikut menyumbang terhadap kesejahteraan mayarakat Indonesia pada umumnya.

\section{Simpulan}

Peran dan status perempuan dalam status social dapt tercermin dalam keterlibatan perempuan itu sendiri pada berbagai aspek kehidupan yang antara lain mencakup kehidupan dibidang rumah tangga, pembangunan, keluarga inti (extended family) maupun keluarga dalam arti luas (nuclear family).

Keterlibatan perempuan dalam berbagai aspek kehidupan social tersebuta akan membawa konsekuensi bahwa perempuan itu merupakan salah satu unsur yang tergabubung dalam satu kesatuan dan menunjukkan adanya saling ketergentungan dengan unsur lainnya. Dalam ketergantungan itu, sekumpulan manusia terintegrasi yangbersifat lebih kekal dan stabil. Selama masing-masing individu dalam kelompok kesatuan tersebur masih menunjukkan adanya kondisi saling ketergantungan dan memiliki kesamaan serta keeimbnagn perilaku maka, selama itu pula unsur-unsur sistem social menjalankan fungsinya. Adapun unsur-unsur social dalam masyarakat itu adalah; status, peranan, dan perbedaan social dari individu individu yang saling berhubungan dalam suatu struktur social.
Status sangat erat kaitannya dengan peranan. Peranan seseorang dilakukan sebesar atau sesuai dengan hak dan keswajibannya yang diatur dalam status. Begitu pula status dan peranan perempuan dalam kehidupan rumah tangga, keluarga, pembangunan maupun pada masyarakat yang lebih luas lagi dialaksanakan sesuai dengan hak dan kewajibannya yang telah diatur dalam kesatuan kelompokkelompok tersebut diamana perempuan itu terlibat. Pelaksanaan hak dan kewajiban tersebut didasarkan pada norma-norma social yang dianggap sebagai pengawal perikelakuan individuindividu agar sesuai dengan status yang dimiliki. Disamping itu dalam kelompok-kelompok sosial tersebut (rumah tangga, keluarga, pembangunan dan sebagainya) terdapat seperangkat seperangkatseperangkat hubungan timbal balik antara peranan-peranan termasuk didalamnya adalah peranan perempuan itu sendiri sehubungan dengan status social masing-masing individu lainnya yang ikut terlibat didalamnya.

\section{Daftar Pustaka}

Abdulsyani. 2002. Sosiologi Skematika, teori dan terapan. Cetakan ke-2, Jakarta: Bumi Aksara.

Arief Budiman. 1985. Pembagian Kerja Seksual Sebuah Pembahasan Sosiologis tentang Peran Wanita dalam Masyarakat. Jakarta: Gramedia. 
| Peranan dan Status Perempuan dalam Sistem Sosial

Boserup Ester. 1984. Peranan Wanita Persepektif Gender. Cetakan ke-2, dalam Perkembangan Ekonomi. Yogyakarta: Sekretariat Bersama Jakarta: Obor Indonesia. $\quad$ Perempuan (SBPY) kerjasama

Fauzie Ridjal dkk. 1993. Dinamika dengan OXFAM UK/1.

Gerakan Perempuan di Indonesia. Yogyakarta: Tiara Wacana.

Utami Munandar. 1985. Emansipasi dan Peran Ganda Wanita Indonesia Suatu Tinjauan Psikologis, Jakarta: Manseour $\quad$ Faqih. $\quad$ 1998. Universitas Indonesia (UI-press).

Merekonstruksi Realitas dengan 
| Puji Lestari

DIMENSIA, Volume 5, No. 1, Maret 2011 | 60 